\title{
NORMAS EDITORIAIS
}

Os Cadernos do Programa de Pós-Graduação em Direito, é uma publicação do Ptogtama de Pós-Graduação em Direito da Faculdade de Direito da Universidade Federal do Rio Grande do Sul (UFRGS).

É um veículo de divulgação científica e cultural, visa servir como meio de difusão de novos conhecimentos e para a troca de idéias entre pesquisadores, estudiosos, profissionais na prática e no desenvolvimento da Ciência do Direito e atividades afins.

É publicado duas vezes ao ano, com periodicidade semestral.

Serão aceitos para publicação ensaios, artigos e resenhas inéditas, aprovados pelo Conselho Editotial.

O Conselho Editorial, reserva-se o direito de realizat as alterações nos originais necessárias à homogeneidade formal da publicação, podendo também solicitart reformas aos autores.

Os textos deverão set entregues, gravados em disquere, acompanhados de uma cópia impressa, com, no máximo, trinta laudas, em papel $A 4$, fonte arial, corpo 12 , entrelinhamento $1,5 \mathrm{~cm}$.

O título do artigo deverá ser breve, específico e descritivo.

O tesumo deverá ser de, no máximo, sessenta palavras, e vir acompanhado de até cinco palavras-chave.

Ilustrações, fotos, tabelas e outros materiais gráficos deverão set acompanhados da especificação de sua fonte e da permissão para reprodução, quando for o caso.

As notas bibliográficas deverão ser especificadas pelo sistema autor, datá, página. Mesmo que o autor não faça uso de notas, deverá indicar as referências bibliogtáficas, cuja exatidão é de sua responsabilidade.

Os trabalhos devem seguir as normas da Associação Brasileira de Normas Técnicas (ABNT), especialmente as mencionadas abaixo:

NBR 6023 - Referências Bibliográficas

NBR 6024 - Numeração Progressiva das Seções de um Documento

NBR 6028 - Resumos

NBR 10520-Apresentação de Citações em Documentos

O autor receberá, como direito autoral, três exemplares do respectivo fascículo. 